\title{
THE RELATIONSHIP BETWEEN TAX BURDEN AND ECONOMIC GROWTH: TURKEY CASE
}

\author{
DOI: 10.17261/Pressacademia.2020.1220 \\ JBEF- V.9-ISS.2-2020(7)-p.143-154
}

\section{Ozay Ozpence ${ }^{1}$, Nedim Mercan ${ }^{2}$}

${ }_{1}^{1}$ Pamukkale University, Faculty of Economics and Administrative Sciences, Department of Public Finance, Denizli, Turkey. oozpence@pau.edu.tr, ORCID: 0000-0003-1502-3240

${ }^{2}$ Pamukkale University, Faculty of Economics and Administrative Sciences, Department of Public Finance, Denizli, Turkey nedimmercann@gmail.com, ORCID: 0000-0002-7604-6828

Date Received: April 22, 2020

Date Accepted: June 14, 2020

To cite this document

Ozpence, O., Mercan, N. (2020). The relationship between tax burden and economic growth: Turkey case. Journal of Business, Economics and Finance (JBEF), V.9(2), p. 143-154.

Permenant link to this document: http://doi.org/10.17261/Pressacademia.2020.1220

Copyright: Published by PressAcademia and limited licensed re-use rights only.

\begin{abstract}
Purpose - In the theoretical framework, the relationship between tax revenues and economic growth, which is the multiplier mechanism, shows that an increase in tax revenues has a negative impact on economic growth. In this study, the relationship between tax burden and economic growth is examined by VAR analysis and Granger causality test.

Methodology - In this study, VAR analysis and Granger Causality test analysis methods are used. In the study, the analysis is done for Turkey. Annual data are used in the study. The analysis covers the years from 1970 to 2018. In the study, firstly VAR analysis is done and then Granger Causality test is performed.

Findings - The findings obtained in the analysis are as follows. In the VAR analysis the tax burden has a negative effect on the 3rd period growth. As a result of the Granger Causality test, it is concluded that tax burden and economic growth are mutual causes of each other.

Conclusion - According to the results obtained, the tax burden affects economic growth negatively. Accordingly, increasing tax rates will not have positive feedback in terms of economic growth, and vice versa, its will have negative effects on economic growth. It would be more positive result, if policy makers reduce their tax rates in practice rather than increasing.
\end{abstract}

Keywords: Tax Burden, Economic Growth, VAR Analysis, Causality, Tax Policy JEL Codes: H20, O10, C50

\section{INTRODUCTION}

States must have a revenue in order to fulfill their public needs. The most important source of revenue of the states is tax revenues and this is the most important feature of taxes. However, in addition to the task of providing public finance, taxes have gradually started to be used for balancing the social and economic order. Economies in the world generally attach great importance to economic growth. But it also gives the same importance to earning an income for growth. Taxes as financing are always important for both developed and developing countries. In the definition of the tax, it is emphasized that it is public revenue and it is also unrequited. How much tax will be collected, how much will be collected from whom and how it will be collected is implemented with different policies for each country.

Taxes as public revenue appear to be a shared financial obligation among all those living under the legal domination of the state (Özpençe and Özpençe, 2007, 3, Özgün et al., 2016, 29 - 30). Economic growth is a sine qua non for the states. In the historical doctrines that started with Mercantilism, they are engaged in the development of growth in the light of various policies. Physiocrats, who say that growth can be by agriculture, oppose the Mercantilist view that growth can be by keeping precious metals in the country. This trend in France explains that taxes should only be charged through agriculture (Higgs, 2001, 19-20). 
Later, the classical school emerged as the basis of modern economics, defended by important figures such as Smith, Ricardo, Malthus and opposed to the intervention of the state by shaping in the framework of liberal policies in general. According to the classics, the basic condition of growth is to have a productive population. It is accepted by many economists that the free market economy is a better system for growth and therefore argues that the state should not interfere with the market (Özpençe, 2017, 33). Smith who referring to the division of labor, argues that labor will specialize in the division of labor, and this specialization will lead to growth (Smith, 1998, 17 - 19)

In the Keynesian school, growth is handled in the short term and argues that it will happen with the increase in demand. The Harrod - Domar growth model, which is referred to as the long - term version of Keynes, states that the increase in investments, such as Keynes, will create a double effect and result in capacity increase and demand effect. Demand effect will also lead to an increase in investment and consumption expenditures (Doğan, 2014, 369). Solow model, which makes various criticisms of Harrod - Domar growth model, states that growth can be achieved with technical developments (Solow, 1956, 65 - 66, Solow, 1957, 312 - 313). Later, the Intrinsic Growth Model emerged, pioneered by Lucas and Romer, evolving with names like Barro and Grossman - Helpman.

The progress of countries towards continuous development also creates new theories in economic theory (Fine, 2000, 245). In this model, it is stated that Romer and Lucas, technological development, R \& D, education investments and human capital investments will provide growth. In addition, Barro states that the investments and expenditures of the public sector in the productive areas will be the factor that provides economic growth (Erdoğan and Canbay, 2016, 36 - 39, Saraç, 2015, 23 - 24, Şiriner and Doğru, 2005, 166 - 167).

It is known that the basis of growth is mainly production, but also growth will be ensured with the increase in production. However, especially after the 1970s, with the globalization, the circulation of production factors becomes free and makes the production process difficult. Especially in developing countries, with the liberalized capital mobility in 1980 and after, growth begins to depend on capital inflows. Since this capital mobility is particularly short-term, growth becomes dependent on high break.

This study explains the concept of the tax burden in Turkey after the first view the relationship between economic growth and the tax burden is then given to literature. Then an econometric study is carried out for Turkey and finally the study is concluded with the results and evaluation part.

\section{TAX BURDEN}

Taxes are income collected and compulsory according to everyone's financial strength in order to cover public expenditures. Everyone pays the tax directly or indirectly. However, taxes are seen as an income for the state and an expense for the payer. As a matter of fact, it is known that the direct and indirect separation of the taxes and the high indirect tax rates in our country do not give tax according to the financial power of people, in this case it forces low income people.

The fact that taxes are unrequited appears to be a burden or discontent for taxpayers (Neumark, 1937, 257, Pehlivan, 2014, 160). This is because it causes a decrease in the economic power of taxpayers, i.e. their income. Naturally, it is normal for people to see conditions that negatively affect their economic power as a burden. It is possible to classify the tax burden into subjective tax burden and objective tax burden. The subjective tax burden is the pressure felt by taxpayers, and this reflects a psychological effect. The objective tax burden is expressed as the ratio between the tax paid by the taxpayers and their income (Inaltong, 2012, 17).

The tax burden can be expressed as the ratio of taxes paid to the total taxable base, although no specific definition is made (Öztürk and Ozansoy, 2011, 198). Tax burden imposes a burden on taxpayers and is important in terms of achieving large-scale targets such as economic growth and income distribution. Tax rates are one of the most important factors affecting tax burden. The high tax rates and the introduction of new taxes increase the pressure on individuals and lead them to look for ways to tax avasion or evade taxes. In this way, the high tax burden reduces the profits of investors and also adversely affects capital investments (Işık and Kılınç, 2009, 150, İdikut Özpençe and İ̧̧ler, 2017, 129).

Previously, A. Laffer drew the relationship between tax rates and tax revenues on napkin paper at a restaurant in Washington in 1974, and after a while he wrote its theory. Since A. Laffer wrote this in 1974, the inverse relationship between tax rates and government revenues has been discussed. It is stated that if the tax rates are high, the incomes of the state will decrease and people will evade the tax and it will have negative effects on the growth. Tax rates should be neither $100 \%$ nor $0 \%$. Because in 
both cases there are negative aspects for both the state and taxpayers (Ballard et al., 1985, 188, Laffer, 2004, 2, Wanniski, 1978, 3-4 (https://www.nationalaffairs.com/public_interest/detail/taxes-revenues-and-the-laffer-curve)) (13.12.2017).

The tax burden is grouped under various names. These groupings are briefly defined as follows. Total tax burden is expressed as the ratio of all taxes collected in a country in a given period to GDP in that period. The total tax burden represents the tax capacity that a country pays over a period. The personal tax burden is defined as the ratio of all taxes paid by a person to all income received during that period. In this way, the tax burden in sectors and regions is expressed in the same logic. As of 2001, Marmara region has the highest regional tax burden and Eastern Anatolia region has the lowest tax burden (Günay, 2007, 5, İnaltong, 2012, 17, Tekbaş and Dökmen, 2007, 203).

The tax burden is directly proportional to the tax paid and inversely proportional to the solvency. In this case, if the amount of tax payable increases, the tax burden increases, and as the solvency increases, a decrease in tax burden occurs. In other words, an increase in the amount of tax paid causes an increase in the tax burden, while an increase in the wealth or income of tax payers reduces the tax burden (Öztürk and Ozansoy, 2011, 199, Çiftçi et al., 2012, 83). It is known that the tax burden should be distributed fairly among sectors, regions, individuals and institutions. The fair and balanced distribution of the tax is important in this regard. In this respect, in most countries, the fair distribution of the tax burden is applied within the framework of laws. In our country, this issue is included in article 73 of the constitution (Rakıcı and Vural, 2011, 62-65). The fair distribution of the tax burden is also important for voluntary compliance. There are several reasons for voluntary compliance. The first is justice, as previously stated, the second is the belief that taxes are used in the public interest, and the third is the fairness of the tax burden (Çiftçi et al., 2012, 84).

Considering the tax burden for Turkey is seen to be particularly much difference between direct taxes and indirect taxes. The status of Turkey's tax revenues are examined in Table 1. It is also stated its share in tax revenues.

Table 1: Share of Income Tax, Corporate Tax and VAT in Budget Revenues

\begin{tabular}{|c|c|c|c|c|c|c|c|c|c|}
\hline Years & Tax Income & $\begin{array}{l}\text { Income Tax } \\
\text { Rev. }\end{array}$ & $\begin{array}{l}\text { Ratio } \\
\text { in Tax } \\
\text { Rev. } \\
\text { (\%) }\end{array}$ & $\begin{array}{l}\text { Corporate } \\
\text { Tax Rev. }\end{array}$ & $\begin{array}{l}\text { Ratio } \\
\text { in Tax } \\
\text { Rev. } \\
\text { (\%) }\end{array}$ & $\begin{array}{l}\text { Total VAT } \\
\text { Rev. } \\
\text { (Domestic + } \\
\text { Import) }\end{array}$ & $\begin{array}{l}\text { Ratio } \\
\text { in Tax } \\
\text { Rev. } \\
\text { (\%) }\end{array}$ & $\begin{array}{l}\text { Income Tax } \\
\text { + Corporate } \\
\text { Tax + VAT } \\
\text { Rev. }\end{array}$ & $\begin{array}{l}\text { Ratio } \\
\text { in Tax } \\
\text { Rev. } \\
\text { (\%) }\end{array}$ \\
\hline 2000 & 26.503 .698 & 6.212 .977 & 23,4 & 2.356 .787 & 8,9 & 8.379 .554 & 31,6 & 16.949 .318 & 64,0 \\
\hline 2001 & 39.735 .928 & 11.579 .424 & 29,1 & 3.675 .665 & 9,3 & 12.438 .860 & 31,3 & 27.693 .949 & 69,7 \\
\hline 2002 & 59.631 .868 & 13.717 .660 & 23,0 & 5.575 .495 & 9,3 & 20.400 .201 & 34,2 & 39.693 .356 & 66,6 \\
\hline 2003 & 84.316 .169 & 17.063 .761 & 20,2 & 8.645 .345 & 10,3 & 27.031 .099 & 32,1 & 52.740 .205 & 62,6 \\
\hline 2004 & 101.038 .904 & 19.689 .593 & 19,5 & 9.619 .359 & 9,5 & 34.325 .208 & 34,0 & 63.634 .160 & 63,0 \\
\hline 2005 & 119.250 .807 & 22.817 .530 & 19,1 & 11.401 .986 & 9,6 & 38.280 .429 & 32,1 & 72.499 .945 & 60,8 \\
\hline 2006 & 151.271 .701 & 31.727 .644 & 21,0 & 12.447 .354 & 8,2 & 50.723 .560 & 33,5 & 94.898 .558 & 62,7 \\
\hline 2007 & 171.098 .466 & 38.061 .543 & 22,2 & 15.718 .474 & 9,2 & 55.461 .123 & 32,4 & 109.241 .140 & 63,8 \\
\hline 2008 & 189.980 .827 & 44.430 .339 & 23,4 & 18.658 .195 & 9,8 & 60.066 .230 & 31,6 & 123.154 .764 & 64,8 \\
\hline 2009 & 196.313.308 & 46.018 .360 & 23,4 & 20.701 .805 & 10,5 & 60.169 .248 & 30,6 & 126.889 .413 & 64,6 \\
\hline 2010 & 235.714 .637 & 49.385 .289 & 21,0 & 22.854 .846 & 9,7 & 75.649 .986 & 32,1 & 147.890 .121 & 62,7 \\
\hline 2011 & 284.490 .017 & 59.885 .000 & 21,0 & 29.233 .725 & 10,3 & 95.550 .463 & 33,6 & 184.669 .188 & 64,9 \\
\hline 2012 & 317.218 .619 & 69.671 .645 & 22,0 & 32.111 .820 & 10,1 & 103.155 .875 & 32,5 & 204.939 .340 & 64,6 \\
\hline 2013 & 367.517 .727 & 78.726 .008 & 21,4 & 31.434 .581 & 8,6 & 123.878 .363 & 33,7 & 234.038 .952 & 63,7 \\
\hline 2014 & 401.683 .956 & 91.063 .306 & 22,7 & 35.163 .517 & 8,8 & 130.538 .554 & 32,5 & 256.765 .377 & 63,9 \\
\hline 2015 & 465.229 .389 & 105.395 .330 & 22,7 & 37.009 .625 & 8,0 & 153.844 .174 & 33,1 & 296.249 .129 & 63,7 \\
\hline 2016 & 529.607 .901 & 123.686 .147 & 23,4 & 46.898 .425 & 8,9 & 168.808 .352 & 31,9 & 339.392 .924 & 64,1 \\
\hline 2017 & 626.082 .415 & 143.962 .939 & 23,0 & 57.868 .208 & 9,2 & 206.679 .678 & 33,0 & 408.510 .825 & 65,2 \\
\hline 2018 & 738.180 .401 & 175.420 .074 & 23,8 & 84.132 .155 & 11,4 & 250.661 .593 & 34,0 & 510.213 .822 & 69,1 \\
\hline
\end{tabular}

Source: GiB (Gelir İdaresi Başkanlığı), (http://www.gib.gov.tr/sites/default/files/fileadmin/user upload/VI/CVI3.htm) (16.10.2019). 
The share of income tax in total tax revenues is calculated as $22.4 \%$ on average. The share of corporate tax in total tax revenues is $9.5 \%$ on average. The share of total VAT in tax revenues is calculated as $32.6 \%$ on average. When we look at the share of the three big taxes in the total tax revenues, it is seen that the average amount is $64.4 \%$. When Table 1 is evaluated in terms of indirect and direct taxes, it is seen that VAT, income tax and corporate tax are higher than the total share of tax revenues.

The tax burden ratio in Turkey is seen in Table 2 below. In addition, OECD's tax burden average is taken in order to make comparisons.

Table 2: GDP, General Budget Tax Revenues, Tax Burden in Turkey and OECD Tax Burden Average

\begin{tabular}{lcccc}
\hline Years & GDP (Thousand TL) & Tax Revenue (Thousand TL) & Tax Burden (\%) (2/1) & OECD Avarage(\%) \\
\hline $\mathbf{2 0 0 2}$ & 359.358 .871 & 59.644 .416 & 16,6 & 33,02 \\
\hline $\mathbf{2 0 0 3}$ & 468.015 .146 & 81.783 .798 & 17,5 & 33,93 \\
\hline $\mathbf{2 0 0 4}$ & 577.023 .497 & 100.373 .326 & 17,4 & 33,89 \\
\hline $\mathbf{2 0 0 5}$ & 673.702 .943 & 119.627 .198 & 17,8 & 33,37 \\
\hline $\mathbf{2 0 0 6}$ & 789.227 .555 & 137.480 .292 & 17,4 & 33,50 \\
\hline $\mathbf{2 0 0 7}$ & 880.460 .879 & 152.835 .111 & 17,4 & 33,57 \\
\hline $\mathbf{2 0 0 8}$ & 994.782 .858 & 168.108 .960 & 16,9 & 33,94 \\
\hline $\mathbf{2 0 0 9}$ & 999.191 .848 & 172.440 .423 & 17,3 & 32,20 \\
\hline $\mathbf{2 0 1 0}$ & 1.160 .013 .978 & 210.560 .388 & 18,2 & 32,29 \\
\hline $\mathbf{2 0 1 1}$ & 1.394 .477 .166 & 253.809 .179 & 18,2 & 32,59 \\
\hline $\mathbf{2 0 1 2}$ & 1.569 .672 .115 & 278.780 .848 & 17,8 & 33,06 \\
\hline $\mathbf{2 0 1 3}$ & 1.809 .713 .087 & 326.169 .164 & 18,0 & 33,35 \\
\hline $\mathbf{2 0 1 4}$ & 2.044 .465 .876 & 352.514 .457 & 17,2 & 33,59 \\
\hline $\mathbf{2 0 1 5}$ & 2.338 .647 .494 & 407.818 .455 & 17,4 & 33,71 \\
\hline $\mathbf{2 0 1 6}$ & 2.608 .525 .749 & 459.001 .741 & 17,6 & 34,42 \\
\hline $\mathbf{2 0 1 7}$ & 3.110 .650 .155 & 536.617 .206 & 17,3 & 34,24 \\
\hline $\mathbf{2 0 1 8}$ & 3.724 .387 .936 & 621.536 .356 & 16,7 & 34,26 \\
\hline
\end{tabular}

Source: a) GiB, (http://www.gib.gov.tr/sites/default/files/fileadmin/user_upload/VI/GBG/Tablo 3.xls.htm) (16.12.2019)

b) OECD, (https://data.oecd.org/tax/tax-revenue.htm) (16.12.2019)

Table 2, there is GDP, tax revenues are the general budget and tax burden in Turkey, while the OECD average tax burden. In terms of years, the lowest tax burden was realized in 2002, while the highest tax burden was realized in 2010 and 2011 . Within the framework of these years, there is not much increase and decrease in tax burden. The average tax burden in Turkey between the years $2002-2018$ is calculated as $17.45 \%$. This average is lower than the average of all OECD countries (33.46\%) in this period. But despite the low of Turkey's tax burden in OECD countries, there is no a fair distribution. The gap between indirect and direct taxes in Turkey explains that the tax burden is not distributed fairly and in a balanced way.

The issue of fair and balanced distribution of the tax burden is expressed even during the II Development Plan. Accordingly, considering the impact of Turkey's current taxation system on the economy, the fair and balanced distribution of the tax burden, increasing the savings amounts in terms of the development of the economy at the desired speed and direction, and distribution is an important factor (Avcl, 1988, 32). One of the reasons why the tax burden in Turkey is lower than the average tax burden of OECD countries is due to the narrow tax base in our country. The fact that taxes are generally take from goods, services and income and also affects the narrowness of the tax base due to the high tax evasion in our country (ilhan, 2007, 7).

\section{LITERATURE REVIEW}

When the literature is examined, various results of the studies that examine the relationship between economic growth and tax are shown in the Table 3. One of the main reasons why the results are different here are the level of development of the countries and the different economic policies they implement.

In the studies we have analyzed, it is seen that generally time series analysis and panel data analysis methods are used. In the literature, only the relationship between tax burden and economic growth is not examined in the general framework. It is also 
involved in studies that address a single specific tax, such as the impact of the indirect tax burden on economic growth. Table 3 in our study is useful to see different analyzes. The reason why different analyses are included in the analysis of tax burden and economic growth is that the issue is multifaceted. When we look at the literature table, Kneller et al. (1999), Lee and Gordon (2005), Arnold (2008), Veronika and Lenka (2012), Demir and Sever (2016) and Stoilava (2017) use panel data analysis. At the same time, Anastassiou and Dritsaki (2005) and Ünlükaplan and Arısoy (2011) use causality tests and Erdoğan et al. (2013) we see that they use cointegration analysis and causality tests. The studies carrying out VAR analysis are Mucuk and Alptekin (2008) and Bacarezza et al. (2013) it can be seen in table 3.

Studies conducted with panel data analysis mostly conclude that the tax burden has a negative effect on economic growth. Unlike these studies, Stoilova (2017), who could not find the same result, concludes that there is a fundamentally positive effect. When we look at the causality test results, it is seen that there is a causality relationship between tax burden and economic growth. In the studies analyzed by VAR analysis, there are studies that have obtained both negative and positive results between tax burden and economic growth. The most effective reason for this is that the economic structures of the countries discussed are different and the periods discussed are different. As a result, developed countries and developing countries are not expected to have the same result. At the same time, cointegration analyzes also determine the existence of a long-term relationship between tax burden and economic growth. Çelikay (2017) can be given as an example. In our study, both the VAR model and causality test analyzes are performed. In our study, as a result, it was partly Bacarezza et al. (2013), Ünlükaplan and Arısoy (2011) and Anastassiou and Dritsaki (2005) have yielded similar results.

Table 3: Empirical Studies on Tax and Economic Growth

\begin{tabular}{|c|c|}
\hline $\begin{array}{l}\text { Author/ Year of the Study/ Country(s)/ } \\
\text { Econometric Method and Years }\end{array}$ & Findings \\
\hline $\begin{array}{l}\text { Kneller et al. (1999)/ } 22 \text { OECD Countries/ } \\
\text { Pane Data Analysis } 1970-1995\end{array}$ & $\begin{array}{l}\text { According to the analysis, it is concluded that distorting taxation affects } \\
\text { growth negatively. }\end{array}$ \\
\hline $\begin{array}{l}\text { Widmalm (2001)/ } 23 \text { OECD Countries/ } \\
\text { Cross Section Analysis } 1965-1990\end{array}$ & The increase in personal income tax adversely affects economic growth. \\
\hline $\begin{array}{l}\text { Anastassiou and Dritsaki (2005)/ } \\
\text { Yunanistan/Granger Causality 1965-2002 }\end{array}$ & $\begin{array}{l}\text { As a result of the research, it was determined that there is a causality } \\
\text { between economic growth and tax revenue. }\end{array}$ \\
\hline $\begin{array}{l}\text { Koch et al. (2005)/ South Africa/ Data } \\
\text { Envelopment Analysis } 1960-2002\end{array}$ & $\begin{array}{l}\text { As a result of the analysis, it is suggested that the decrease in tax burden is } \\
\text { related to economic growth and the decrease in indirect taxes is effective } \\
\text { in economic growth. }\end{array}$ \\
\hline $\begin{array}{l}\text { Lee and Gordon (2005)/ } 70 \text { Countries/ } \\
\text { Panel Data, Cross Section Analysis and } \\
\text { Regression Analysis } 1970-1997\end{array}$ & $\begin{array}{l}\text { The } 10 \% \text { decrease in corporate tax will increase economic growth by } 1 \% \\
\text { and } 2 \% \text {. }\end{array}$ \\
\hline $\begin{array}{l}\text { Arnold (2008)/ } 21 \text { OECD Countries/ Panel } \\
\text { Data Analysis } 1971-2004\end{array}$ & $\begin{array}{l}\text { In the analysis, it is concluded that income tax has a negative effect on more } \\
\text { economic growth than consumption tax and wealth tax. }\end{array}$ \\
\hline $\begin{array}{l}\text { Mucuk and Alptekin (2008)/ Turkey/ VAR } \\
\text { Analysis } 1975-2006\end{array}$ & $\begin{array}{l}\text { As a result of cointegration test, the variables move together and as a result } \\
\text { of causality test, it is concluded that there is a one-way relationship from } \\
\text { direct taxes to economic growth. }\end{array}$ \\
\hline $\begin{array}{l}\text { Ünlükaplan and Arısoy (2011)/ Turkey/ } \\
\text { Granger Causality, Cointegration Analysis } \\
\text { and Impact - Response Analysis } 1968 \text { - } \\
2006\end{array}$ & $\begin{array}{l}\text { According to the results of cointegration, a relationship was found between } \\
\text { the tax burden and real GNP. According to the causality test, economic } \\
\text { growth and tax burden are the cause of each other in the long run. } \\
\text { According to the impact response analysis, an external shock on the tax } \\
\text { burden creates a static effect. }\end{array}$ \\
\hline $\begin{array}{l}\text { Veronika and Lenka (2012)/ } 27 \text { EU } \\
\text { Countries/ Panel Data } 1998-2010\end{array}$ & $\begin{array}{l}\text { In the analysis, it has been concluded that the increase in corporate tax } \\
\text { adversely affects economic growth in the long run. }\end{array}$ \\
\hline $\begin{array}{l}\text { Bacarezza et al. (2013)/ } 17 \text { Latin American } \\
\text { Countries and } 81 \text { Latin American Country } \\
\text { / VAR Analysis and Panel Data Analysis } \\
1990-2009\end{array}$ & $\begin{array}{l}\text { In Latin American countries, there is generally no significant negative } \\
\text { relationship between income tax and economic growth, and in } 81 \text { countries } \\
\text { there is a negative relationship between income tax and economic growth. } \\
\text { It has been suggested that reducing corporate tax may affect the economy } \\
\text { positively. }\end{array}$ \\
\hline
\end{tabular}




\begin{tabular}{ll}
\hline $\begin{array}{l}\text { Erdoğan et al. (2013)/ Turkey/ } \\
\text { Cointegration and Causality Analysis 1998 } \\
-2011\end{array}$ & $\begin{array}{l}\text { A long-term relationship was found between indirect taxes and economic } \\
\text { growth. In addition, a one-way causality has been identified from indirect } \\
\text { tax revenues to economic growth in the short and long term. }\end{array}$ \\
\hline $\begin{array}{l}\text { Saraç (2015)/ Turkey/ Markov Regime } \\
\text { Change Technique 1969-2013 }\end{array}$ & $\begin{array}{l}\text { In the periods of contraction and expansion of the economy, the increase } \\
\text { in direct taxes negatively and indirect taxes increase positive affects } \\
\text { economic growth. }\end{array}$ \\
\hline $\begin{array}{l}\text { Demir and Sever (2016)/ 11 OECD } \\
\text { Countries/ Panel Data 1980-2014 }\end{array}$ & $\begin{array}{l}\text { In the long term, a one-unit increase in direct taxes leads to a decrease in } \\
\text { the income level of 0.13 units. In the short term, a one-unit increase in total } \\
\text { taxes leads to a decrease in the income level of 0.17 units. }\end{array}$ \\
\hline $\begin{array}{l}\text { Çelikay (2017)/ Turkey/ ARDL Boundary } \\
\text { Test Approach 1924 - 2014 }\end{array}$ & $\begin{array}{l}\text { The 1\% increase in GDP per capita has a positive effect of approximately } \\
0.07 \% \text { on the tax burden in the long term. }\end{array}$ \\
\hline $\begin{array}{l}\text { Stoilova (2017)/ EU Countries (28)/ Panel } \\
\text { Data Regression 1996-2013 }\end{array}$ & $\begin{array}{l}\text { The tax structure based on excise taxes, personal income and property tax } \\
\text { positively affects economic growth. }\end{array}$ \\
\hline
\end{tabular}

\section{MODEL AND METHODOLOGY}

This study examines the relationship between tax burden and economic growth. The data used in the study were taken from GIB and OECD database. Data on tax burden (Total Taxes / GDP) and economic growth cover the period from 1970 to 2018 . The data obtained are annual data. VAR analysis and Granger causality test are used in the study. VAR analysis is a method that shows the effects of the variables used on each other. Brief representation of the data used in the study is as follows.

Economic growth: GDP

Tax burden: TB

$\operatorname{Var}$ (Vector Autoregresive Model) analysis method was developed by Sims in 1980. It addresses the variables at hand in a whole without any constraints on the model. It examines the relationships between macroeconomic variables. It is a model used to analyze the dynamic effects of a random shock in variables on other variables. This method is one of the most widely used methods because it gives dynamic relationships without any constraints to the structural model (Mucuk and Alptekin, 2008, 162 - 163, Özgen and Güloğlu, 2004, 95 - 97).

Accordingly, it is possible to formulate the VAR model in our study as standard as follows:

$$
\begin{aligned}
& \mathrm{GDP}_{\mathrm{t}}=\alpha 0+\sum_{p=1}^{k} \beta_{1 \mathrm{p}} \Delta \mathrm{TB}_{\mathrm{t}-\mathrm{p}}+\sum_{p=1}^{k} \mu_{1 \mathrm{p}} \mathrm{GDP}_{\mathrm{t}-\mathrm{p}}+\varepsilon_{1 \mathrm{t}} \\
& \Delta \mathrm{TB}_{\mathrm{t}}=\alpha 0+\sum_{p=1}^{k} \mu_{2 \mathrm{p}} \mathrm{GDP}_{\mathrm{t}-\mathrm{p}}+\sum_{p=1}^{k} \beta_{1 \mathrm{p}} \Delta \mathrm{TB}_{\mathrm{t}-\mathrm{p}}+\varepsilon_{2 \mathrm{t}} \\
& \text { k: Lag Length, } \quad \Delta \text { : } \quad \Delta a p \text { Parameter } \\
& \mathrm{t} \text { : Time, } \quad \mu \text { : GDP Stability Coefficient } \\
& \text { p: Lag Coefficient, } \quad \varepsilon \text { : Error Term } \\
& \text { ß: Tax Burden Stability Coefficient, }
\end{aligned}
$$

\subsection{Ampirical Findings}

In an economic analysis, first of all, it is checked whether the data to be used is stationary. The most commonly used methods to test whether the time series are stationary are known as Augmented Dickey - Fuller (ADF) developed by Dickey and Fuller (1979), and Phillips - Perron (PP) unit root tests developed by Phillips Perron (1988). In order for the time series to be used to give more meaningful results, the parameters should not contain a unit root. In other words. $\mathrm{HO}$ is rejected in the hypothesis test.

ADF and PP tests give almost the same results. The PP test is a recommended error correction model for the ADF during the testing process. Hypotheses are presented as follows (Güvenek et al., 2010: 7):

HO: $p=0$ the series is not static, there is a unit root in the series.

$\mathrm{H} 1: \mathrm{p}<0$ the series is stationary, there is no unit root in the series.

The time series should be stationary in the generated models. If time series is not stationary, it can lead to spurious regression. The fact that time series are stationary causes the analysis to be more meaningful and more consistent. As Granger and Newbold 
(1974) stated in their study, the problem of spurious regression occurs when analyzed with non-static time series. In this case, the results obtained are not real results and do not reflect the correct result (Gujarati, 2001, 726).

In the analysis, descriptive statistics related to the study are evaluated first. Then, ADF and PP tests are used to examine the stagnation of economic growth and tax burden series.

\begin{tabular}{lcc}
\multicolumn{3}{l}{ Table 4: Descriptive Statistics of Economic Growth and Tax Burden } \\
\hline Statistics / Variables & GDP & Tax Burden \\
\hline Mean & 4.5617 & 17.6467 \\
\hline Median & 5.1666 & 16.2940 \\
\hline Maximum & 11.1135 & 25.8990 \\
\hline Minimum & -5.9623 & 9.0610 \\
\hline Standart Deviation & 4.1196 & 5.7934 \\
\hline Skewness & -0.8522 & 0.1364 \\
\hline Kurtosis & 3.1774 & 1.3594 \\
\hline Jarque Bera & 5.7516 & 5.4166 \\
\hline
\end{tabular}

When Table 4 is examined, it is seen that descriptive statistics of variables are included. When we look at the Skewness coefficient, it is skewed to the right in the growth data and left to skewed in the tax burden data. When we look at the kurtosis coefficient, it is seen that the variables have a basic and normal distribution respectively.

Table 5 contains the results of the stationarity analysis of the tax burden and economic growth variables in the model of the study according to the Augmented Dickey - Fuller (ADF) and Philips - Peron (PP) unit root tests.

Table 5: Unit Root Tests and Results

\begin{tabular}{|c|c|c|c|c|c|}
\hline \multicolumn{6}{|c|}{ Augmented Dickey - Fuller (ADF) Test } \\
\hline \multirow[t]{2}{*}{ Variables } & & \multicolumn{2}{|c|}{ Constant } & \multicolumn{2}{|c|}{ Constant + Trend } \\
\hline & & t- Stat. & Prob. & t- Stat. & Prob. \\
\hline \multirow[t]{2}{*}{ Level } & GDP & -6.5307 & $0.0000^{*}$ & -6.4636 & $0.0000^{*}$ \\
\hline & TB & -0.7449 & 0.8248 & -1.8180 & 0.6797 \\
\hline $\begin{array}{l}\text { First } \\
\text { Differens }\end{array}$ & TB & -6.5782 & $0.0000 *$ & -6.4966 & $0.0000^{*}$ \\
\hline \multicolumn{6}{|c|}{ Philips - Peron (PP) Testi } \\
\hline \multirow[t]{2}{*}{ Variables } & & \multicolumn{2}{|c|}{ Constant } & \multicolumn{2}{|c|}{ Constant + Trend } \\
\hline & & t- Stat. & Prob. & t- Stat. & Prob. \\
\hline \multirow[t]{2}{*}{ Level } & GDP & -6.5263 & $0.0000^{*}$ & -6.4567 & $0.0000^{*}$ \\
\hline & TB & -0.7459 & 0.8246 & -1.9766 & 0.5983 \\
\hline $\begin{array}{l}\text { First } \\
\text { Differens }\end{array}$ & TB & -6.5786 & $0.0000^{*}$ & -6.4952 & $0.0000^{*}$ \\
\hline
\end{tabular}

*1\% meaning level does not contain unit roots.

Table 5 shows the ADF and PP test results. According to these results, while the GDP level is stable, the tax burden is stable at the meaning level of $1 \%$ when the first difference is received. Both variables were not stable at the same level. In this case, cointegration analysis is not possible and the analysis is continued with VAR model. In the VAR model, stationary states of the series are used. Therefore, the GDP level value is included in the analysis and the tax burden is included in the analysis by taking the first difference.

Information criteria for determining the lag length of the model are given in Table 6. In the model, the minimum number of lag without autocorrelation and changing variance problems is 4 . 
Table 6: Determination of Lag Length

\begin{tabular}{lccccc}
\hline Lag & LR & FPE & AIC & SC & HQ \\
\hline $\mathbf{0}$ & NA & 19.97148 & 8.67004 & $8.75278^{*}$ & $8.70037^{*}$ \\
\hline $\mathbf{1}$ & 0.66553 & 23.76434 & 8.84345 & 9.09169 & 8.93444 \\
\hline $\mathbf{2}$ & 8.49449 & 22.89373 & 8.80434 & 9.21807 & 8.95599 \\
\hline $\mathbf{3}$ & 4.94578 & 24.14410 & 8.85351 & 9.43274 & 9.06582 \\
\hline $\mathbf{4}$ & $16.0381^{*}$ & $18.09664^{*}$ & $8.55798^{*}$ & 9.30270 & 8.83095 \\
\hline
\end{tabular}

In the following figure 1, it is seen that in the case of the stagnation and the appropriate delay of the variables (4), all inverse roots are located in the unit circle. As here, the fact that whole inverse units roots are in the circle indicates that the model is stable.

Figure 1: Inverse Roots Unit Circle

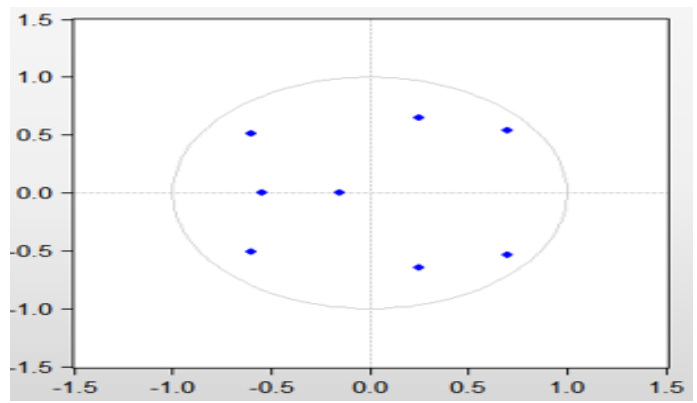

Table 7: LM Autocorrelation Test

\begin{tabular}{lll}
\hline Lag & LM Stat. & Prob. \\
\hline $\mathbf{1}$ & 3.749386 & 0.4410 \\
\hline $\mathbf{2}$ & 3.191514 & 0.5263 \\
\hline $\mathbf{3}$ & 2.439615 & 0.6555 \\
\hline
\end{tabular}

Table 8: Heteroscedasticity Test

\begin{tabular}{lll}
\hline \multicolumn{3}{l}{ White Heteroskedasticity (No Cross Terms) } \\
\hline Chi - Square & df & Prob. \\
\hline $\mathbf{5 2 . 0 1 0 1 2}$ & 48 & 0.3206 \\
\hline
\end{tabular}

Table 7 and Table 8 show that there are no autocorrelation and heteroscedasticity problems at the lag level determined in the model.

When we look at the graphs in Figure 2, the other two graphs, except the graphs at the top right and bottom left, explain the relationship with each other. In this context there is no need to interpret these figures. In the top right graph interpretation of impact-response analysis, the tax burden is 3rd period negatively affects growth. The bottom left graph of the impact-response analysis cannot be statistically interpreted. 
Figure 2: Impact - Response Analysis

Response of BuY to BUY

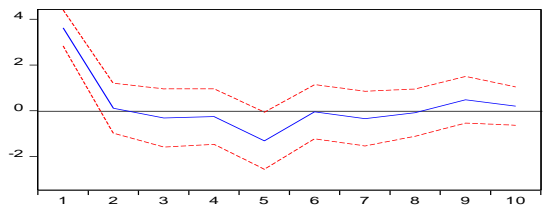

Response of DVY to BUY

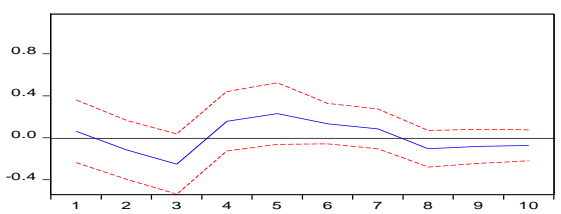

Response of BUY to DVY

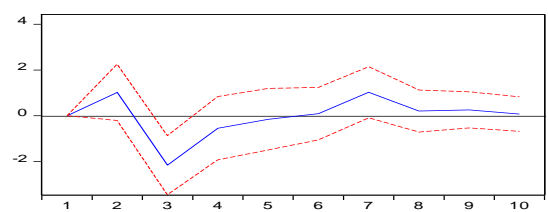

Response of DVY to DVY

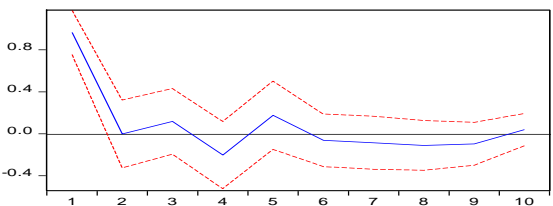

Table 9: Variance Decomposition

\begin{tabular}{cccccc}
\hline \multicolumn{1}{l}{ GDP } & \multicolumn{3}{c}{ TB } & \\
\hline Period & GDP & TB & Period & GDP & TB \\
\hline $\mathbf{1}$ & 100.0000 & 0.000000 & $\mathbf{1}$ & 0.404135 & 99.59587 \\
\hline $\mathbf{2}$ & 92.67264 & 7.327363 & $\mathbf{2}$ & 1.801845 & 98.19816 \\
\hline $\mathbf{3}$ & 69.84528 & 30.15472 & $\mathbf{3}$ & 7.834719 & 92.16528 \\
\hline $\mathbf{4}$ & 68.86636 & 31.13364 & $\mathbf{4}$ & 9.630685 & 90.36932 \\
\hline $\mathbf{5}$ & 71.34127 & 28.65873 & $\mathbf{5}$ & 13.42937 & 86.57063 \\
\hline $\mathbf{6}$ & 71.31679 & 28.68321 & $\mathbf{6}$ & 14.68163 & 85.31837 \\
\hline $\mathbf{7}$ & 68.10333 & 31.89667 & $\mathbf{7}$ & 15.08737 & 84.91263 \\
\hline $\mathbf{8}$ & 67.98622 & 32.01378 & $\mathbf{8}$ & 15.69576 & 84.30424 \\
\hline $\mathbf{9}$ & 68.11935 & 31.88065 & $\mathbf{9}$ & 16.03787 & 83.96213 \\
\hline $\mathbf{1 0}$ & 68.15956 & 31.84044 & $\mathbf{1 0}$ & 16.36768 & 83.63232
\end{tabular}

When Table 9 is generally evaluated, the impact of economic growth on itself is decreasing and economic growth is increasing to be affected by the tax burden. By the 10th period, $31.84 \%$ of economic growth appears to be due to the tax burden. When the tax burden assessment is examined, it is seen that the impact of tax burden on itself is quite high. In the 10 th period, $16.36 \%$ of the tax burden is due to economic growth.

Table 10: VAR Granger Causality Test

\begin{tabular}{lllll}
\hline Explanation & GDP & & TB & \\
\hline GDP & ---- & & Chi - Square & Prob. \\
\cline { 2 - 3 } & & & 17.51533 & 0.0015 \\
\hline TB & Chi - Square & Prob. & --- & \\
\cline { 2 - 3 } & 9.184847 & 0.0566 & & \\
\hline
\end{tabular}

Table 10 shows the results of the Granger causality test between tax burden and economic growth. When the table is examined, the tax burden and economic growth emerges as a result of each other at the meaning level of $10 \%$. As a result, it is concluded that tax burden negatively affects economic growth in impact-response analysis, economic growth is increasingly affected by tax burden in variance decomposition, and causality test is mutually related. These results support each other. 


\section{CONCLUSION}

In this study, the period between 1970 and 2018 is examined in Turkey. In addition, the study is tested with VAR analysis and Granger causality test. As a result of VAR analysis, it is seen that tax burden negatively affects economic growth in the 3rd period. According to the results of Granger causality test, it is concluded that tax burden and economic growth are the mutual cause of each other. When the variance decomposition results are examined, it is observed that the tax burden effect gradually increases despite the fact (68.15) that growth is mostly affected by itself in the 10th period (31.84). Tax burden, again, is mostly affected by itself in the 10th period (83.63). The rate of self-impact of the tax burden is gradually decreasing and the share of economic growth is gradually increasing (16.36).

In this respect, the negative impact of the tax burden on economic growth is a good result for the review of tax policies. Accordingly, increasing tax rates will not have positive feedbacks in terms of economic growth, and vice versa. Policymakers would be more positive in practice to decrease tax rates rather than increase tax rates. In this context, various policy proposals can be presented.

One of these recommendations may be to alleviate the excessive tax burden on the minimum wage. There is an excessive tax burden with indirect taxes paid due to direct taxes and expenditures. According to the Constitution, the principle of fair distribution of taxes can be revised here. Another suggestion should be taken into account in regional factors when calculating the minimum wage. Moreover, increasing the rate of a significant tax, such as corporate tax, may negatively affect economic growth. Although the countries in the world intend to reduce corporate tax in order to attract investment, the desire to increase in our country may not have a positive effect on the economy.

It is known that income tax creates a higher tax burden for the middle-income citizens in Turkey. This situation leads to a tax system which is not functioning properly. This can be solved by spreading the tax to a wide base. High tax rates are the most important reason for the high tax burden. Therefore, high tax rates bring about tax evasion. Moreover, the fact that the indirect tax rates are high is an extra tax burden on low-income citizens. The more fair distribution of taxes is one of the most important duties of the state. Finally, tax policies should be implemented in a simpler and more voluntary tax compliance with low tax rates.

\section{REFERENCES}

Anastassiou, Thomas and Dritsaki, Chaido (2005). Tax Revenues and Economic Growth: An Emprical Investigation for Greece Using Causality Analysis, Journal of Social Sciences, 1, 2, $99-104$. DOI : 10.3844/jssp.2005.99.104

Arnold, Jens (2008). Do Tax Structures Affect Aggregate Economic Growth? Emprical Evidence from A Panel of OECD Countries, Economics Department Working Papers, No: 643, 1 - 28. DOI: 10.1787/18151973

Avcı, Nihal (1988). Bütçe ve Para Politikalarının Makroekonomik Etkileri, Devlet Bütçe Uzmanlığı Araştırma Raporu, Ankara. (http://www.bumko.gov.tr/Eklenti/5474,navcipdf.pdf?0) (15.11.2019).

Bacarreza, G. Canavire., Vazquez, J. Martinez and Vulovic, Violeta (2013). Taxation and Economic Growth in Latin America, IDB Working Paper Series, No: IDB-WP-431, $1-44$.

Ballard, Charles L., Fullerton, Don, Shoven, John. B. and Whalley, John (1985). The Relationship between Tax Rates and Government Revenue, University of Chicago Press, 188 - 202.

Çelikay, Ferdi (2017). Milli Gelirin Vergi Yükü Üzerindeki Etkileri: ARDL Sınır Testi Yaklaşımı ile Türkiye Üzerine Bir İnceleme (1924 - 2014, Sosyoekonomi Dergisi, Vol: 25 (32), 169 - 188. DOI: 10.17233/sosyoekonomi.286478

Çiftçi, Taha E., Kılıçer, Erkan and Peker, İmren (2012). Vergi Yükünün Düşürülmesine İmkan Yaratılması Bağlamında Alternatif Gelir Kaynakları, Hukuk ve İktisat Araştırmaları Dergisi, Cilt: 4, No: 2, 81 - 90.

Demir, Murat and Sever, Erşan (2016). Vergi Gelirleri Ekonomik Büyüme iliş̧kisi: OECD Ülkelerine İlişkin Panel Veri Analizi, Econ World, (http://london2016.econworld.org/papers/Demir_Sever_Relationship.pdf) (16.10.2019).

Doğan, Zehra (2014). Ekonomik Büyüme Süreçlerinin Analizinde Yeni Açılımlar ve Büyümenin Yersel Dinamikleri, Akademik Sosyal Araştırmalar Dergisi, Yıl: 2, Sayı: 6, 365 - 380. DOI : 10.16992/ASOS.339 
Erdoğan, Ebru, Topçu, Mert and Bahar, Ozan (2013). Vergi Gelirleri ve Ekonomik Büyüme Iliş̧kisi: Türkiye Ekonomisi Üzerine Eşbütünleşme ve Nedensellik Analizi, Finans Politik \& Ekonomik Yorumlar, Cilt: 50, Sayı: 576, $99-109$.

Erdoğan, Seyfettin and Canbay, Şerif (2016). İktisadi Büyüme ve Araştırma \& Geliştirme (Ar-Ge) Harcamaları ilişsisi Üzerine Teorik Bir İnceleme, Muş Alparslan Üniversitesi Sosyal Bilimler Dergisi, Cilt: 4, Sayı: 2, 29 - 44. DOI: 10.18506/anemon.16169

Fine, Ben (2000). Endogenous Growth Theory: A Critical Assessment, Cambridge Journal of Economics, 24, 245 - 265. DOI:10.1093/cje/24.2.245

GiB, www.gib.gov.tr (15.12.2017).

Günay, Kerem (2007). Türkiye'de Vergi Yükü ve Kapasitesi Hesaplaması Üzerinde Örnek Bir Çalışma, 1 - 15. (https://www.vergiportali.com/doc/Vergikapasitesi.pdf) (15.10.2019).

Higgs, Henry (2001). The Physiocrats, Canada: Batoche Boks Limited.

Işık, Nihat and Kılınç, Efe Can (2009). OECD Ülkelerinde Vergi Yükü ve Vergi Türleri: Karşılaştırmalı Bir Analiz, KMU iïBF Dergisi, Yıl: 11, Sayı: 17, 147 -173 .

Illhan, Gökalp (2007). Vergi Ödemeyi Etkileyen Ekonomik Faktörler, Akademik Bakış Uluslararası Hakemli Sosyal Bilimler E - Dergisi, Sayı: 12, 1 13.

İnaltong, Ceyhan (2012). Vergi Yükü: Tükiye ve OECD Ülkeleri Karşılaştırması, Vergi Dünyası Dergisi, Sayı: 369, 16 - 30.

Kneller, Richard A., Bleaney, Micheal F. and Gemmell, Norman b. (1999). Fiscal Policy and Growth: Evidence from OECD Countries, Journal of Public Economics, 74, 171 - 190. DOI:10.1016/S0047-2727(99)00022-5

Koch, Steven F., Schoeman, Niek J. and Tonder, J. J. Van (2005). Economic Growth and The Structure of Taxes in South Africa: 1960 - 2002, South Africa Journal of Economics, Vol: 73, 2, 190 - 2010. DOI:10.1111/j.1813-6982.2005.00013.x

Laffer, Arthur (2006). The Laffer Curve: Past, Present and Future, The Heritage Foundation, No: 1765, 1 - 16.

Lee, Young and Gordon, Roger H. (2005). Tax Structure and Economic Growth, Journal of Public Economics, 89, 1027 - 1043. DOI:10.1016/j.jpubeco.2004.07.002

Mucuk, Mehmet and Alptekin, Volkan (2008). Türkiye'de Vergi ve Ekonomik Büyüme ilişkisi: VAR Analizi (1975 - 2006), Maliye Dergisi, Sayı: 155, $159-174$.

Neumark, Fritz (1937). Vergi Yükü ve İktisadi Hayat, İstanbul Üniversitesi Hukuk Fakültesi Mecmuası, (Çev: Sabri F. Ülgener), 247 - 261.

OECD, http://www.oecd.org/ (15.08.2019)

Özgen, Ferhat B. and Güloğlu, Bülent (2004). Türkiye'de iç̧ Borçların İktisadi Etkilerinin VAR Tekniği ile Analizi, METU Studies in Development, 3,93 $-114$.

Özgün, Mehmet, Özkanca Andıç, Nagihan and İşler, İsmail (2016). Vergi Direnci ve Vergi Ahlakı Kavramları Işığında Pamukkale Üniversitesi Öğrencilerinin Vergi Kaçaklığına Bakış Açısı, Mali Kılavuz, Yıl: 18, Sayı: 73, 29 - 43.

Özpençe, Aylin İ. (2017). Türkiye’de 1980 Sonrası Kamu Harcamaları, Vergi Gelirleri ve Ekonomik Büyüme Arasındaki Ilişkinin Analizi, Pamukkale Üniversitesi Sosyal Bilimler Enstitüsü Dergisi, Sayı: 28, 31 - 41. DOI: 10.5505/pausbed.2017.13549

Özpençe, Aylin İ. and İşler, İsmail (2017). Türkiye'de KDV Sorunları ve Avrupa Birliği Ülkelerindeki KDV'nin Kamu Gelirleri ve GSYH İçerisindeki Payları, Vergi Raporu Dergisi, Yıl: 25, Sayı: 2019, 118 - 130.

Özpençe, Aylin I. and Özpençe, Özay (2007). Küreselleşme ve Uluslararası Kuruluşların Ulus - Devletin Vergilendirme Yetkisine Etkileri, Uluslararası İnsan Bilimleri Dergisi, Cilt: 4, Sayı: 1, 1-21.

Öztürk, İlhami and Ozansoy, Ahmet (2011). Ücret Gelirleri Üzerindeki Vergi Yükünün Analizi, Maliye Dergisi, Sayı: 161, 197 - 214.

Pehlivan, Osman (2014). Kamu Maliyesi, Celepler Matbaacılık, Trabzon.

Rakıcı, Cemil and Vural, Tarık (2011). Asgari Ücret Üzerindeki Toplam Vergi Yükü ve Asgari Ücret Tutarının Anlamı, Ekonomi Bilimleri Dergisi, Cilt: 3, No: $2,57-68$.

Saraç, T. Bahadır (2015). Vergi Yükü ve Ekonomik Büyüme ilişkisi: Türkiye Örneği, Maliye Dergisi, Sayı: 169, 21 - 35.

Smith, Adam (1998). An Inquiry into The Nature and Causes of The Wealth of Nations, London: The Elecbook Book Company. 
Solow, Robert M. (1956). A Contribution to The Theory of Economic Growth, The MIT Press, The Quarterly Journal of Economics, Vol: 70, No: 1, 65 - 94. DOI: $10.2307 / 1884513$

Solow, Robert M. (1957). Technical Change and The Aggregate Production Function, The MIT Pres, The Review of Economics and Statistics, Vol: 39, No: 3, 312 - 320. DOI: 10.2307/1926047

Stoilova, Desislava (2017). Tax Structure and Economic Growth: Evidence from The European Union, Contaduria y Administracion, 62, 1041 - 1057. DOI:10.1016/j.cya.2017.04.006

Şiriner, İsmail and Doğru, Yılmaz (2005). Türkiye Ekonomisi'nin Büyüme Dinamikleri Üzerine Bir Değerlendirme, Yönetim Bilimleri Dergisi, (3: 2), $162-182$.

Tekbaş, Abdullah and Dökmen, Gökhan (2007). Türkiye’de Vergi Yükünün Bölgesel Dağılımı, Maliye Dergisi, Sayı: 153, 195 - 2013.

Ünlükapan, illter and Arısoy, İbrahim (2011). Vergi Yükü ve Yapısı ile İktisadi Büyüme Arasındaki Dinamik Etkileşimler Üzerine Uygulamalı Bir Analiz, ODTÜ Gelişme Dergisi, 38, $71-100$.

Veronika, Baranova and Lenka, Janickova (2012). Taxation of Corporations and Their Impact on Economic Growth: The Case of EU Countries, Journal of Competitiveness, Vol: 4, Issue: 4, 96 - 108. DOI: 10.7441/joc.2012.04.07

Wanniski, Jude (1978). Taxes, Revenues, and The 'Laffer Curve', National Affairs, No: 33, (https://www.nationalaffairs.com/) (13.12.2019).

Widmalm, Frida (2001). Tax Structure and Growth: Are Some Taxes Better Than Others?, Public Choice, Vol: 107, No: 3/4, 199 - 219. 